\title{
The Estimation of Human Resources Management Practices' Share in Employees Performance of Iran Public Sector
}

\author{
Alborz Gheitani (Corresponding author) \\ Ph.D Student of Public Management Department, \\ Qazvin Branch, Islamic Azad University, Qazvin, Iran
}

Tel: 98-912-368-3521_E-mail: alborz_gheitani@yahoo.com

\author{
Memarzade Tehran \\ Associate of Public Management Department, \\ Science and Research Branch, \\ Islamic Azad University, Tehran \\ Tel: 98-912-198-5003E-mail: hmemar@ut.ac.ir
}

Saeed Safari

Lecturer at Department of Industrial Management

Chief of Entrepreneurship Centre

Shahed University, Tehran, Iran

Tel: 98-215-121-3508-12Ｅ-mail: Safari@ shahed.ac.ir

Received: Feb. 8, 2013 Accepted: May 6, $2013 \quad$ Published: July 1, 2013

doi:10.5296/jmr.v5i3.3232 URL: http://dx.doi.org/10.5296/jmr.v5i3.3232

\begin{abstract}
Human resource management (HRM) is a very important issue in new century and doing its practices in the right mood can lead organizations to success. The final goal of each HRM system is to achieve optimum employee performance, and this will be realized through HRM practices. However, there are several practices are conducted in HRM that their importance is not same. Therefore, in this study authors sought to estimate the share of each HRM system
\end{abstract}


practice in public sector employee performance. Since practices aren't independent, their correlations should be considered in estimation. So analytical network process (ANP) was used for estimation, and it was an innovation in HRM field. The data was gathered by pair wise comparisons questionnaire from an experts group. Results showed the share of each practice of HRM system in public sector employee performance.

Keywords: HRM practices share, Employee performance, Analytical network process, HRM system, Public sector 


\section{Introduction}

Management is one of the important issues in new age. Many organizations have reached to big success by proper management, and many other organizations have gone to lose caused to management mistakes. One of the most important of management field is employee management that is called Human Resource Management (HRM). Aim of HRM is to provide techniques for employee management and help to employee performance improvement in organization (soadat, 2007). HRM is one of the most important factors in total quality and productivity of public and private sector organizations, and finally is the principal of economic, social and cultural development (Mirsepasi, 2004). HRM is strategic and stable management of the most valuable resources of organization (human resources).

HRM, generally, is a system of practices and sub-practices that seeks employees' performance improvement in a way that individual, organizational and social goals achieved (Mirsepasi, 2004). As follows, HRM practices have a direct effect on performance. The central argument in the configurational perspective is that the impact of HRM on organizational performance is dependent on the adoption of an effective combination of HRM practices (Dewettinck and Remue,2011). HRM practices impacts positively on organizational outcomes (Gill and Meyer, 2011). HRM practices and policies promote competitive capacity of organization (Lengnick-Hall and et al, 2012). How the overall set of HRM practices may effect on organizational competitive advantage (Singh and et al. 2012). HRM practices can build a positive cycle of trust (Vanhala, Ahteela, 2011), that it is the most important item for social capital. How the HRM practices effect on employee participation, and it has a positive impact on performance (Menezes, 2012).

Nevertheless, the effect of these practices and on performance is not same. However previous studies have not mentioned to this point. On the other hand, these practices correlate with each other, and the correlations should be considered in estimation. Based on these explanations ANP method was used for estimating the share of HRM practices in performance, and it is an innovation in HRM field.

Share estimation of practices can help to plan and organizing the HRM. Information of HRM practices' shares in performance can help managers to allocate resources appropriately. Then in this paper, authors sought to find the share of each HRM practice and sub-practice in employee performance.

For this purpose at first HRM and its practices have been defined. Then used methodology has been provided. Afterward how the data collection, data and results have been explained. Finally, authors have described conclusions and results.

\section{Human resources management (HRM) and its practices}

Othman (1996) points out that there are four meanings frequently attached to HRM. The first is that HRM is simply just another word for personnel management and is also used to cover other concepts such as employee relations and people management. The second meaning refers to the use of specific personnel management techniques in an integrated manner. In this definition, HRM is seen as the unified and coherent use of policies and techniques such as 
selection, performance appraisal, reward and training to enhance organizational performance. The third meaning emphasizes the importance of a business-oriented and business- integrated approach in the management of employees. This definition emphasizes that the way an organization manages its workforce should match the strategy it pursues. The term "strategic HRM" is often used to refer to this strategically oriented HRM practice. The fourth definition goes to a step further; besides the importance of integration with strategy, it also emphasizes the use of employee management techniques, which seek to develop employee commitment to certain desired outcomes.

HRM is integrated and strategic approach to manage the most valuable capital of company. HR as a most valuable capital has the biggest contribution to organizational achievement. Attitudes to HRM are divided into three approaches)( Armstrong, 2009: 27): high performance management (effects on organizational performance through employees by productivity, quality, levels of delivery improvement of customer services, and more value creation for shareholders), high commitment management (with emphasis on mutual commitment between individual and organization that leads to organizational goal achievement without formal control mechanisms), and high participation management (dealing with employees as partners whom they can decide issues facing related to them).

HRM practices are the activities pursued to fulfill the core tasks of HRM (Mayrhofer et al., 2011). HRM practices create procedures that institutionalize the building of employees' knowledge, skills, and abilities throughout the organization to promote valued, unique, and difficult to imitate organizational competencies which support competitive advantage (Werbel and DeMarie, 2005). In view of Bjorkmana et al. (2008) central aspects of HRM practices are: recruitment and selection, training, financial compensation, and performance appraisal. Murphy and Murrmann (2009) use three HRM practices category:

(1) Employee development. Organizations invest in human capital since, at the organizational level, employee training generates substantial gains such as increased productivity, profitability and market valuation. Investment in employees is sometimes even seen as a 'cure-all' in turbulent environments leading to comparative advantage. Hence, calls for more investment into employee development abound at the level of national politics as well as at the organizational level. However, depending on the educational system and its impact on the educational level of the work force, the role of trade unions and employers' associations, or legal regulations concerning financing training and development measures employee development measures are subject to contextual variations.

(2) Employee rewards. A key focus for organizations is the provision of monetary and non-monetary incentives for work, often linked to the individual's contribution to the organizational results. Organizational pay systems are related to a number of issues such as individual output, retention and voluntary turnover strategy orientation, or organizational performance. In line with the global tendencies towards flexibility and performance orientation, the use of rewarding mechanisms linked to different aspects of individual and organizational performance has been emphasized in academic and practitioner discourses. However, reward practices are affected by cultural and institutional factors. Examples include 
culturally acceptable income differentials, norms and values about rewarding individuals or collectives, or legally applied minimum wages and trade union pressures.

(3) Employee communication. The handling of the internal communication flow is crucial for organizations. It may take individual or collective forms. At the individual level it has, among others, positive effects for commitment or job satisfaction. The collective forms of employee communication include both union-centered and non-union mechanisms. Nevertheless, they point out that degree and kind of communication is strongly influenced by contextual factors such as culture-related communication norms or the role of trade unions or works councils.

Researchers investigating the links among human resource management (HRM) practices, sustainable competitive advantage (SCA) and firm performance, including Cappelli and Singh (1992), Wright and McMahan (1992), Pfeffer (1994), Lado and Wilson (1994), Huselid (1995), Jackson and Schuler (1995), Becker and Gerhart (1996), Delaney and Huselid (1996), Boxall (1998), Pfeffer (1998), Schuler and Jackson (2000), Ulrich and Beatty (2001), Lepak and Snell (2002) have studied the effects of single or multiple HRM variables on firm performance. These efforts have led to the incremental development of strategic human resource management (SHRM) theory that stresses the relationships between the HRM practices and firm performance (Murphy and Murrmann, 2009). According to Puc $\mathrm{e}^{\bullet}$ taite (2010) Previous research indicates that HRM practices such as fair and just selection and hiring, evaluation, rewarding, dismissal can contribute positively to organizational trust. Thus, it can be stated that fair and just HRM practices may enhance employees' self-regulation and motivate them to act in a predictable and trustworthy way at least for economic reasons and this leads to better performance.

Over the years, researchers have suggested many HRM practices that have the potential to improve and sustain organizational performance. These practices include emphasis on employee selection based on fit with the company's culture, emphasis on behavior, attitude, and necessary technical skills required by the job, compensation contingent on performance, and employee empowerment to foster team work, among others (Ahmada and Schroeder, 2003). The practices proposed are: (1) Employment security. (2) Selective hiring of new personnel. (3) Self-managed teams and decentralization of decision making as the basic principles of organizational design. (4) Comparatively high compensation contingent on organizational performance. (5) Extensive training. (6) Reduced status distinctions and barriers, including dress, language, office arrangements, and wage differences across levels. (7) Extensive sharing of financial and performance information throughout the organization. The literature has emphasized the need for generalizability of the relationship between HRM practices and organizational performance.

HRM effects on performance more than special attention on HRM practices. In other words, HRM is seen as an interacting complex of components rather than as some apparent activities (Becker \& Huselid, 1999; Huselid, 1995; Wright and Snell, 1998; Lengnick-Hall, 2009).

Devanna, Fombrun, and Tichy (1984) believe that human resources managers make systematic use of strategically based selection, individual performance appraisal, individual performance-related rewards, and outcome-monitored training and development as means to 
enhancing performance. Mirsepassi (2004) listed four systems for HRM. These four systems are: (1) absorption, preparation, and adjustment system; (2) training and development system; (3) maintain and protection system; and (4) application. He has considered 14 sub-practices for these systems that shown below, and these sub-practices are used for this study:

Absorption, preparation, and adjustment system: Estimated manpower requirement or surplus, Predicted staffing or moderating methods, Employment Selection, Appointment

Training and development system: Employees training and education, Performance management

Maintain and protection system: compensation, Employees health, Insurance and retirement, Welfare services

Application: Leadership, Communication and motivation, Movement quitting and discipline

\section{Methodology and data collection}

As cited before, HRM practices correlate each other, and for accurate estimation these correlations should be considered. Analytical Network Process was used to estimate HRM practices and sub-practices share in performance. In this method, the decision maker can build a network instead of hierarchical structure. Therefore, in this way, the inner relations between variables can be studied. In Analytical Hierarchy Process (AHP), it is assumed different levels of hierarchy are independent. Even so, in the real world we face with more complicated problems, and problems can't be formulated as a hierarchical model because in many cases, factors interact with each other. In these cases, there are correlation relations between decision options. Saaty (1999) has provided ANP for these problems. In these issues, indexes and options aren't independent thus ANP method overcomes one of the limitations of AHP that is the assumption of independent between options and indexes (Atayi, 2009: 239-240).

With these explanations, clearly many pair wise comparisons were needed for this method to study the inner relation between all factors. For pair wise comparisons, researcher built questionnaire was distributed in the experts group. Experts group was selected by snowball method. Because authors' goal was to study the public sector, experts group was asked to their responses in relation to human resource performance in public organizations. Whereas in this method is not easy to create consensus among expert group members, the best way to combine individual judgment is to use geometric mean (Aezel and Saaty, 1983).

\section{Result}

Based on ANP method, at first, it needed to obtain matrix weights of the initial super matrix. For this purpose, equation 1 was used.

$$
W=\lim _{k \rightarrow \infty} \frac{A^{k} \cdot e}{e^{T} \cdot A^{k} \cdot e}
$$

In this equation: 
$\mathrm{W}=$ Eigen vector.

$\mathrm{A}=$ Obtained pair wise comparison matrix.

Table1. initial super matrix

\begin{tabular}{|c|r|r|r|r|r|r|r|r|r|r|r|r|r|r|r|r|r|r|r|}
\hline & \multicolumn{1}{|c|}{ goal } & APA & TD & MP & A & EM & PS & S & E & A & PM & T & C & H & IR & W & L & CM & M \\
\hline APA & 0.3508 & 0 & 0.4327 & 0.3684 & 0.5665 & 0 & 0 & 0 & 0 & 0 & 0 & 0 & 0 & 0 & 0 & 0 & 0 & 0 & 0 \\
\hline TD & 0.1453 & 0.3914 & 0 & 0.3861 & 0.2621 & 0 & 0 & 0 & 0 & 0 & 0 & 0 & 0 & 0 & 0 & 0 & 0 & 0 & 0 \\
\hline MP & 0.2538 & 0.2926 & 0.4023 & 0 & 0.1714 & 0 & 0 & 0 & 0 & 0 & 0 & 0 & 0 & 0 & 0 & 0 & 0 & 0 & 0 \\
\hline A & 0.25 & 0.316 & 0.165 & 0.2455 & 0 & 0 & 0 & 0 & 0 & 0 & 0 & 0 & 0 & 0 & 0 & 0 & 0 & 0 & 0 \\
\hline EM & 0 & 0.1623 & 0 & 0 & 0 & 0 & 0 & 0 & 0 & 0 & 0 & 0 & 0 & 0 & 0 & 0 & 0 & 0 & 0 \\
\hline PS & 0 & 0.1615 & 0 & 0 & 0 & 0 & 0 & 0 & 0 & 0 & 0 & 0 & 0 & 0 & 0 & 0 & 0 & 0 & 0 \\
\hline S & 0 & 0.2746 & 0 & 0 & 0 & 0 & 0 & 0 & 0 & 0 & 0 & 0 & 0 & 0 & 0 & 0 & 0 & 0 & 0 \\
\hline E & 0 & 0.166 & 0 & 0 & 0 & 0 & 0 & 0 & 0 & 0 & 0 & 0 & 0 & 0 & 0 & 0 & 0 & 0 & 0 \\
\hline A & 0 & 0.2355 & 0 & 0 & 0 & 0 & 0 & 0 & 0 & 0 & 0 & 0 & 0 & 0 & 0 & 0 & 0 & 0 & 0 \\
\hline PM & 0 & 0 & 0.8162 & 0 & 0 & 0 & 0 & 0 & 0 & 0 & 0 & 0 & 0 & 0 & 0 & 0 & 0 & 0 & 0 \\
\hline T & 0 & 0 & 0.1838 & 0 & 0 & 0 & 0 & 0 & 0 & 0 & 0 & 0 & 0 & 0 & 0 & 0 & 0 & 0 & 0 \\
\hline C & 0 & 0 & 0 & 0.5186 & 0 & 0 & 0 & 0 & 0 & 0 & 0 & 0 & 0 & 0 & 0 & 0 & 0 & 0 & 0 \\
\hline H & 0 & 0 & 0 & 0.1911 & 0 & 0 & 0 & 0 & 0 & 0 & 0 & 0 & 0 & 0 & 0 & 0 & 0 & 0 & 0 \\
\hline IR & 0 & 0 & 0 & 0.1558 & 0 & 0 & 0 & 0 & 0 & 0 & 0 & 0 & 0 & 0 & 0 & 0 & 0 & 0 & 0 \\
\hline W & 0 & 0 & 0 & 0.1345 & 0 & 0 & 0 & 0 & 0 & 0 & 0 & 0 & 0 & 0 & 0 & 0 & 0 & 0 & 0 \\
\hline L & 0 & 0 & 0 & 0 & 0.5489 & 0 & 0 & 0 & 0 & 0 & 0 & 0 & 0 & 0 & 0 & 0 & 0 & 0 & 0 \\
\hline CM & 0 & 0 & 0 & 0 & 0.2944 & 0 & 0 & 0 & 0 & 0 & 0 & 0 & 0 & 0 & 0 & 0 & 0 & 0 & 0 \\
\hline M & 0 & 0 & 0 & 0 & 0.1567 & 0 & 0 & 0 & 0 & 0 & 0 & 0 & 0 & 0 & 0 & 0 & 0 & 0 & 0 \\
\hline
\end{tabular}

Table 1 shows initial super matrix that obtained from experts group views. Because of inner relations of factors in ANP, the sum of elements in a column is more than 1.Then the matrix should be weighted. It accomplished by normalization the elements of the matrix columns. The results of the normalized initial super matrix are shown in table 2. For final judgment and prioritize options and different practices and sub-practices, the limiting priorities of the matrix as it represents all possible interactions in the system should be obtained. The limiting priorities of the matrix are achieved by equation 2 (Saaty, Vargas, 2006).

$$
\text { Limiting super matrix }=\lim _{k \rightarrow \infty}\left(\frac{1}{2}\right) \sum w_{i}^{k}
$$


Table 2. weighted super matrix

\begin{tabular}{|c|c|c|c|c|c|c|c|c|c|c|c|c|c|c|c|c|c|c|c|}
\hline & goal & APA & TD & MP & A & $\begin{array}{l}\mathrm{E} \\
\mathrm{M}\end{array}$ & $\begin{array}{l}\mathrm{P} \\
\mathrm{S}\end{array}$ & $\mathrm{S}$ & E & A & $\begin{array}{l}\mathrm{P} \\
\mathrm{M}\end{array}$ & $\mathrm{T}$ & $\mathrm{C}$ & $\mathrm{H}$ & $\begin{array}{l}\mathrm{I} \\
\mathrm{R}\end{array}$ & W & L & $\begin{array}{l}\mathrm{C} \\
\mathrm{M}\end{array}$ & M \\
\hline $\begin{array}{l}\text { AP } \\
\text { A }\end{array}$ & $\begin{array}{r}0.350 \\
8\end{array}$ & 0 & $\begin{array}{r}0.2163 \\
5\end{array}$ & 0.1842 & $\begin{array}{r}0.2832 \\
5\end{array}$ & 0 & 0 & 0 & 0 & 0 & 0 & 0 & 0 & 0 & 0 & 0 & 0 & 0 & 0 \\
\hline TD & $\begin{array}{r}0.145 \\
3\end{array}$ & 0.19571 & 0 & $\begin{array}{r}0.1930 \\
5\end{array}$ & $\begin{array}{r}0.1310 \\
5\end{array}$ & 0 & 0 & 0 & 0 & 0 & 0 & 0 & 0 & 0 & 0 & 0 & 0 & 0 & 0 \\
\hline MP & $\begin{array}{r}0.253 \\
8\end{array}$ & $\begin{array}{r}0.14630 \\
7\end{array}$ & $\begin{array}{r}0.2011 \\
5\end{array}$ & 0 & 0.0857 & 0 & 0 & 0 & 0 & 0 & 0 & 0 & 0 & 0 & 0 & 0 & 0 & 0 & 0 \\
\hline A & 0.25 & $\begin{array}{r}0.15800 \\
8\end{array}$ & 0.0825 & $\begin{array}{r}0.1227 \\
5\end{array}$ & 0 & 0 & 0 & 0 & 0 & 0 & 0 & 0 & 0 & 0 & 0 & 0 & 0 & 0 & 0 \\
\hline EM & 0 & $\begin{array}{r}0.08115 \\
4\end{array}$ & 0 & 0 & 0 & 0 & 0 & 0 & 0 & 0 & 0 & 0 & 0 & 0 & 0 & 0 & 0 & 0 & 0 \\
\hline PS & 0 & $\begin{array}{r}0.08075 \\
4\end{array}$ & 0 & 0 & 0 & 0 & 0 & 0 & 0 & 0 & 0 & 0 & 0 & 0 & 0 & 0 & 0 & 0 & 0 \\
\hline $\mathrm{S}$ & 0 & $\begin{array}{r}0.13730 \\
7\end{array}$ & 0 & 0 & 0 & 0 & 0 & 0 & 0 & 0 & 0 & 0 & 0 & 0 & 0 & 0 & 0 & 0 & 0 \\
\hline E & 0 & $\begin{array}{r}0.08300 \\
4\end{array}$ & 0 & 0 & 0 & 0 & 0 & 0 & 0 & 0 & 0 & 0 & 0 & 0 & 0 & 0 & 0 & 0 & 0 \\
\hline IA & 0 & $\begin{array}{r}0.11775 \\
6\end{array}$ & 0 & 0 & 0 & 0 & 0 & 0 & 0 & 0 & 0 & 0 & 0 & 0 & 0 & 0 & 0 & 0 & 0 \\
\hline PM & 0 & 0 & 0.4081 & 0 & 0 & 0 & 0 & 0 & 0 & 0 & 0 & 0 & 0 & 0 & 0 & 0 & 0 & 0 & 0 \\
\hline $\mathrm{T}$ & 0 & 0 & 0.0919 & 0 & 0 & 0 & 0 & 0 & 0 & 0 & 0 & 0 & 0 & 0 & 0 & 0 & 0 & 0 & 0 \\
\hline $\mathrm{C}$ & 0 & 0 & 0 & 0.2593 & 0 & 0 & 0 & 0 & 0 & 0 & 0 & 0 & 0 & 0 & 0 & 0 & 0 & 0 & 0 \\
\hline $\mathrm{H}$ & 0 & 0 & 0 & $\begin{array}{r}0.0955 \\
5\end{array}$ & 0 & 0 & 0 & 0 & 0 & 0 & 0 & 0 & 0 & 0 & 0 & 0 & 0 & 0 & 0 \\
\hline IR & 0 & 0 & 0 & 0.0779 & 0 & 0 & 0 & 0 & 0 & 0 & 0 & 0 & 0 & 0 & 0 & 0 & 0 & 0 & 0 \\
\hline W & 0 & 0 & 0 & $\begin{array}{r}0.0672 \\
5\end{array}$ & 0 & 0 & 0 & 0 & 0 & 0 & 0 & 0 & 0 & 0 & 0 & 0 & 0 & 0 & 0 \\
\hline $\mathrm{L}$ & 0 & 0 & 0 & 0 & $\begin{array}{r}0.2744 \\
5\end{array}$ & 0 & 0 & 0 & 0 & 0 & 0 & 0 & 0 & 0 & 0 & 0 & 0 & 0 & 0 \\
\hline $\mathrm{CM}$ & 0 & 0 & 0 & 0 & 0.1472 & 0 & 0 & 0 & 0 & 0 & 0 & 0 & 0 & 0 & 0 & 0 & 0 & 0 & 0 \\
\hline M & 0 & 0 & 0 & 0 & $\begin{array}{r}0.0783 \\
5\end{array}$ & 0 & 0 & 0 & 0 & 0 & 0 & 0 & 0 & 0 & 0 & 0 & 0 & 0 & 0 \\
\hline
\end{tabular}

Calculations have been done by using MATLAB software, and results are shown in table 3. With normalizing the weights of items HRM the shares of each HRM sub-practice are characterized. It is shown in table 4. 
Table 3. The Synthesized or Limiting super matrix

\begin{tabular}{|c|c|c|c|c|c|c|c|c|c|c|c|c|c|c|c|c|c|c|c|}
\hline & $\begin{array}{c}\text { goa } \\
1\end{array}$ & $\begin{array}{l}\mathrm{AP} \\
\mathrm{A}\end{array}$ & TD & MP & A & EM & PS & $\mathrm{S}$ & E & A & PM & $\mathrm{T}$ & C & $\mathrm{H}$ & IR & W & L & $\mathrm{CM}$ & $\mathrm{M}$ \\
\hline A & 0.2 & 0.2 & 0.2 & 0.2 & 0.2 & 0.2 & 0.2 & 0.2 & 0.2 & 0.2 & 0.2 & 0.2 & 0.2 & 0.2 & 0.2 & 0.2 & 0.2 & 0.2 & 0.2 \\
\hline $\begin{array}{l}P \\
A\end{array}$ & 099 & 099 & 099 & 099 & 099 & 099 & 099 & 099 & 099 & 099 & 099 & 099 & 099 & 099 & 099 & 099 & 099 & 099 & 099 \\
\hline $\mathrm{T}$ & 0.1 & 0.1 & 0.1 & 0.1 & 0.1 & 0.1 & 0.1 & 0.1 & 0.1 & 0.1 & 0.1 & 0.1 & 0.1 & 0.1 & 0.1 & 0.1 & 0.1 & 0.1 & 0.1 \\
\hline D & 321 & 321 & 321 & 321 & 321 & 321 & 321 & 321 & 321 & 321 & 321 & 321 & 321 & 321 & 321 & 321 & 321 & 321 & 321 \\
\hline $\mathrm{M}$ & 0.1 & 0.1 & 0.1 & 0.1 & 0.1 & 0.1 & 0.1 & 0.1 & 0.1 & 0.1 & 0.1 & 0.1 & 0.1 & 0.1 & 0.1 & 0.1 & 0.1 & 0.1 & 0.1 \\
\hline $\mathrm{P}$ & 571 & 571 & 571 & 571 & 571 & 571 & 571 & 571 & 571 & 571 & 571 & 571 & 571 & 571 & 571 & 571 & 571 & 571 & 571 \\
\hline \multirow[t]{2}{*}{ A } & 0.1 & 0.1 & 0.1 & 0.1 & 0.1 & 0.1 & 0.1 & 0.1 & 0.1 & 0.1 & 0.1 & 0.1 & 0.1 & 0.1 & 0.1 & 0.1 & 0.1 & 0.1 & 0.1 \\
\hline & 571 & 571 & 571 & 571 & 571 & 571 & 571 & 571 & 571 & 571 & 571 & 571 & 571 & 571 & 571 & 571 & 571 & 571 & 571 \\
\hline E & 0.0 & 0.0 & 0.0 & 0.0 & 0.0 & 0.0 & 0.0 & 0.0 & 0.0 & 0.0 & 0.0 & 0.0 & 0.0 & 0.0 & 0.0 & 0.0 & 0.0 & 0.0 & 0.0 \\
\hline $\mathrm{M}$ & 159 & 159 & 159 & 159 & 159 & 159 & 159 & 159 & 159 & 159 & 159 & 159 & 159 & 159 & 159 & 159 & 159 & 159 & 159 \\
\hline $\mathrm{P}$ & 0.0 & 0.0 & 0.0 & 0.0 & 0.0 & 0.0 & 0.0 & 0.0 & 0.0 & 0.0 & 0.0 & 0.0 & 0.0 & 0.0 & 0.0 & 0.0 & 0.0 & 0.0 & 0.0 \\
\hline $\mathrm{S}$ & 159 & 159 & 159 & 159 & 159 & 159 & 159 & 159 & 159 & 159 & 159 & 159 & 159 & 159 & 159 & 159 & 159 & 159 & 159 \\
\hline \multirow[t]{2}{*}{$\mathrm{S}$} & 0.0 & 0.0 & 0.0 & 0.0 & 0.0 & 0.0 & 0.0 & 0.0 & 0.0 & 0.0 & 0.0 & 0.0 & 0.0 & 0.0 & 0.0 & 0.0 & 0.0 & 0.0 & 0.0 \\
\hline & 27 & 27 & 27 & 27 & 27 & 27 & 27 & 27 & 27 & 27 & 27 & 27 & 27 & 27 & 27 & 27 & 27 & 27 & 27 \\
\hline \multirow[t]{2}{*}{ E } & 0.0 & 0.0 & 0.0 & 0.0 & 0.0 & 0.0 & 0.0 & 0.0 & 0.0 & 0.0 & 0.0 & 0.0 & 0.0 & 0.0 & 0.0 & 0.0 & 0.0 & 0.0 & 0.0 \\
\hline & 163 & 163 & 163 & 163 & 163 & 163 & 163 & 163 & 163 & 163 & 163 & 163 & 163 & 163 & 163 & 163 & 163 & 163 & 163 \\
\hline \multirow[t]{2}{*}{ IA } & 0.0 & 0.0 & 0.0 & 0.0 & 0.0 & 0.0 & 0.0 & 0.0 & 0.0 & 0.0 & 0.0 & 0.0 & 0.0 & 0.0 & 0.0 & 0.0 & 0.0 & 0.0 & 0.0 \\
\hline & 231 & 231 & 231 & 231 & 231 & 231 & 231 & 231 & 231 & 231 & 231 & 231 & 231 & 231 & 231 & 231 & 231 & 231 & 231 \\
\hline $\mathrm{P}$ & 0.0 & 0.0 & 0.0 & 0.0 & 0.0 & 0.0 & 0.0 & 0.0 & 0.0 & 0.0 & 0.0 & 0.0 & 0.0 & 0.0 & 0.0 & 0.0 & 0.0 & 0.0 & 0.0 \\
\hline M & 954 & 954 & 954 & 954 & 954 & 954 & 954 & 954 & 954 & 954 & 954 & 954 & 954 & 954 & 954 & 954 & 954 & 954 & 954 \\
\hline \multirow[t]{2}{*}{$\mathrm{T}$} & 0.0 & 0.0 & 0.0 & 0.0 & 0.0 & 0.0 & 0.0 & 0.0 & 0.0 & 0.0 & 0.0 & 0.0 & 0.0 & 0.0 & 0.0 & 0.0 & 0.0 & 0.0 & 0.0 \\
\hline & 215 & 215 & 215 & 215 & 215 & 215 & 215 & 215 & 215 & 215 & 215 & 215 & 215 & 215 & 215 & 215 & 215 & 215 & 215 \\
\hline \multirow[t]{2}{*}{$\mathrm{C}$} & 0.0 & 0.0 & 0.0 & 0.0 & 0.0 & 0.0 & 0.0 & 0.0 & 0.0 & 0.0 & 0.0 & 0.0 & 0.0 & 0.0 & 0.0 & 0.0 & 0.0 & 0.0 & 0.0 \\
\hline & 606 & 606 & 606 & 606 & 606 & 606 & 606 & 606 & 606 & 606 & 606 & 606 & 606 & 606 & 606 & 606 & 606 & 606 & 606 \\
\hline \multirow[t]{2}{*}{$\mathrm{H}$} & 0.0 & 0.0 & 0.0 & 0.0 & 0.0 & 0.0 & 0.0 & 0.0 & 0.0 & 0.0 & 0.0 & 0.0 & 0.0 & 0.0 & 0.0 & 0.0 & 0.0 & 0.0 & 0.0 \\
\hline & 223 & 223 & 223 & 223 & 223 & 223 & 223 & 223 & 223 & 223 & 223 & 223 & 223 & 223 & 223 & 223 & 223 & 223 & 223 \\
\hline \multirow[t]{2}{*}{ IR } & 0.0 & 0.0 & 0.0 & 0.0 & 0.0 & 0.0 & 0.0 & 0.0 & 0.0 & 0.0 & 0.0 & 0.0 & 0.0 & 0.0 & 0.0 & 0.0 & 0.0 & 0.0 & 0.0 \\
\hline & 182 & 182 & 182 & 182 & 182 & 182 & 182 & 182 & 182 & 182 & 182 & 182 & 182 & 182 & 182 & 182 & 182 & 182 & 182 \\
\hline \multirow[t]{2}{*}{ W } & 0.0 & 0.0 & 0.0 & 0.0 & 0.0 & 0.0 & 0.0 & 0.0 & 0.0 & 0.0 & 0.0 & 0.0 & 0.0 & 0.0 & 0.0 & 0.0 & 0.0 & 0.0 & 0.0 \\
\hline & 157 & 157 & 157 & 157 & 157 & 157 & 157 & 157 & 157 & 157 & 157 & 157 & 157 & 157 & 157 & 157 & 157 & 157 & 157 \\
\hline \multirow[t]{2}{*}{$\mathrm{L}$} & 0.0 & 0.0 & 0.0 & 0.0 & 0.0 & 0.0 & 0.0 & 0.0 & 0.0 & 0.0 & 0.0 & 0.0 & 0.0 & 0.0 & 0.0 & 0.0 & 0.0 & 0.0 & 0.0 \\
\hline & 065 & 065 & 065 & 065 & 065 & 065 & 065 & 065 & 065 & 065 & 065 & 065 & 065 & 065 & 065 & 065 & 065 & 065 & 065 \\
\hline $\mathrm{C}$ & 0.0 & 0.0 & 0.0 & 0.0 & 0.0 & 0.0 & 0.0 & 0.0 & 0.0 & 0.0 & 0.0 & 0.0 & 0.0 & 0.0 & 0.0 & 0.0 & 0.0 & 0.0 & 0.0 \\
\hline $\mathrm{M}$ & 035 & 035 & 035 & 035 & 035 & 035 & 035 & 035 & 035 & 035 & 035 & 035 & 035 & 035 & 035 & 035 & 035 & 035 & 035 \\
\hline \multirow[t]{2}{*}{$\mathrm{M}$} & 0.00 & 0.00 & 0.00 & 0.00 & 0.00 & 0.00 & 0.00 & 0.00 & 0.00 & 0.00 & 0.00 & 0.00 & 0.00 & 0.00 & 0.00 & 0.00 & 0.00 & 0.00 & 0.00 \\
\hline & 19 & 19 & 19 & 19 & 19 & 19 & 19 & 19 & 19 & 19 & 19 & 19 & 19 & 19 & 19 & 19 & 19 & 19 & 19 \\
\hline
\end{tabular}




\section{Conclusion}

Based on previous researches and literature review that have mentioned in this paper it is obviously clear that HRM practices effect on employee performance. However, previous studies have not focused on difference of these practices' share in employee's performance. More ever in this paper has been tried to consider the inner relations between practices, and for this reason the ANP method was used. Using this method for issues like this is innovative and this adds the value of the study. Results was shown that the performance management' share was the largest share in employees performance of Iran public sector and the compensation was after that. The share' sequence of other practices was respectively: Selection; Appointment; Employees training and education; Employees health; Estimated manpower requirement or surplus; Predicted staffing or moderating methods; Employment; Insurance and retirement; Welfare services; Leadership; Communication and motivation; Movement quitting and discipline. These results show managers should pay particular attention to performance management and compensation practices, and should invest more time and energy on these practices. Based on the results the share of HRM practices in performance are different, then future researchers should consider it in their researches and therefore these results can be used as the primary data by other researchers for future researches. On the other hand, according the literature review social, cultural and environmental situation effect on the importance and preferences of practices, hence researchers from other countries can do the same work in their countries and compare their results with this paper. For greater accuracy and higher reliability future researchers also can do the estimation with fuzzy ANP.

Table 4. Sub-practices' share in employee performance

\begin{tabular}{|l|r|r|r|r|r|r|r|r|r|r|r|r|r|r|}
\hline & EM & PS & S & E & A & PM & T & C & H & IR & W & L & CM & M \\
\hline$\times$ & 0.046 & 0.046 & 0.078 & 0.047 & 0.067 & 0.277 & 0.062 & 0.176 & 0.064 & 0.052 & 0.045 & 0.018 & 0.010 & 0.005 \\
100 & 248 & 248 & 534 & 411 & 19 & 487 & 536 & 265 & 863 & 938 & 666 & 906 & 18 & 526 \\
\hline & 4.624 & 4.624 & 7.853 & 4.741 & 6.719 & 27.74 & 6.253 & 17.62 & 6.486 & 5.293 & 4.566 & 1.890 & 1.018 & 0.552 \\
& 782 & 782 & 403 & 129 & 023 & 869 & 636 & 653 & 329 & 775 & 608 & 634 & 034 & 647 \\
\hline & 5 & 5 & 8 & 5 & 7 & 27 & 6 & 17 & 6 & 5 & 5 & 2 & 1 & 1 \\
\hline
\end{tabular}

Note: In tables $\mathrm{APA}=$ Absorption, preparation, and adjustment system; $\mathrm{TD}=$ Training and development system; $\mathrm{MP}=$ Maintain and protection system; $\mathrm{A}=$ Application; $\mathrm{EM}=$ Estimated manpower requirement or surplus; $\mathrm{PS}=$ Predicted staffing or moderating methods; $\mathrm{S}=$ Selection; $\mathrm{E}=$ Employment; $\mathrm{A}=$ Appointment; $\mathrm{PM}=$ Performance management; $\mathrm{T}=$ Employees training and education; $\mathrm{C}=$ compensation; $\mathrm{H}=$ Employees health; $\mathrm{IR}=$ Insurance and retirement; $\mathrm{W}=$ Welfare services; $\mathrm{L}=$ Leadership; $\mathrm{CM}=$ Communication and motivation; $\mathrm{M}=$ Movement quitting and discipline.

\section{References}

Aczel, dan Saaty (1983). Procedures for synthesising ratio judgements. Journal Math Psychol, 27, 93-102. http://dx.doi.org/10.1016/0022-2496(83)90028-7 
Ahmada S., \& R. G. Schroeder. (2003). The impact of human resource management practices on operational performance: recognizing country and industry differences. Journal of Operations Management, 21, 19-43. http://dx.doi.org/10.1016/S0272-6963(02)00056-6

Armstrong, M. (2010). Translated by M. Arrabi, O. Mahdie, Strategic Human Resources Management. Cultural Researches Office, third edition (in Farsi)

Atayi M. (2007). Multi Criteria Decision Making. Industrial University of Shahrood (In Farsi).

Becker, B. E., \& Huselid, M. A. (1999). Overview: Strategic human resource management in five leading firms. Human Resource Management, 38(4), 287-301. http://dx.doi.org/10.1002/(SICI)1099-050X(199924)38:4<287::AID-HRM2>3.0.CO;2-L

Bjorkmana I., A. Smaleb,J. Sumeliusa, V, \& Suutarib, Y. Lu, (2008). Changes in institutional context and MNC operations in China: Subsidiary HRM practices in 1996 versus 2006. International Business Review, 17, 146-158. http://dx.doi.org/10.1016/j.ibusrev.2008.02.001

Bourdieu, P. (1983). Forms of capital'. In: Richardson, J. (Ed.), Handbook of Theory and Research for the Sociology of Education. Greenwood Press, New York, pp. 241-258.

Cappelli P., \& Singh H. (1992). Integrating strategic human resources and strategic management. Research Frontiers in Industrial Relations and Human Resources, 165-192.

Devanna, M., L. Fombrun, \& N. Tichy. (1984). A framework for strategic human resource management, in C. Fombrun, N. Tichy, and M. Devanna, (Eds), Strategic Human Resource Management, Wiley, New York, NY.

Dewettinck k., \& J. Remue, (2011). Contextualizing HRM in comparative research: The role of the Cranet network. Human Resource Management Review, 21, 37-49. http://dx.doi.org/10.1016/j.hrmr.2010.09.010

Gill, C., \& D. Meyer (2011). The role and impact of HRM policy. International Journal of Organizational Analysis, 19(1), 5-28. http://dx.doi.org/10.1108/19348831111121286

Huselid M.A. (1995). The impact of human resource practices on turnover, productivity, and corporate financial performance. Academy of Management Journal, 38, 635-667. http://dx.doi.org/10.2307/256741

Huselid, M. A. (1995). The impact of human resource management practices on turnover, productivity, and corporate financial performance. Academy of Management Journal, 38(3), 635-670. http://dx.doi.org/10.2307/256741

Jackson, S.E., \& Schuler, R.S. (1995). Understanding human resource management in the context of organizations and their environments. Annual Review of Psychology, 46, 237-265. http://dx.doi.org/10.1146/annurev.ps.46.020195.001321

Lado A., \& A.Wilson, M.C., (1994). Human resource systems and sustained competitive advantage: a competency-based perspective. The Academy of Management Review, 19(4), 
699-729.

Lengnick-Hall, C. A., T. E. Beck B, \& M. L. Lengnick-Hall. (2010). Developing a capacity for organizational resilience through strategic human resource management. Human Resource Management Review, 21(3), 243-255. http://dx.doi.org/10.1016/j.hrmr.2010.07.001

Lengnick-Hall, M. L. C. A. Lengnick-Hall, L.S. Andrade, \& B. Drake. (2009). Strategic human resource management: The evolution of the field. Human Resource Management Review, 19(2), 64-85. http://dx.doi.org/10.1016/j.hrmr.2009.01.002

Lepak D., \& Snell A. (2002). Examining the human resource architecture: the relationships among human capital, employment, and human resource configurations. Journal of Management, 28(4), 517-543.

Mayrhofer W., C. Brewster, M. J. Morley, \& J. Ledolter. (2011). Hearing a different drummer? Convergence of human resource management in Europe - A longitudinal analysis. Human Resource Management Review, 21, 50-67. http://dx.doi.org/10.1016/j.hrmr.2010.09.011

Menezes, L. M. de, (2012). Job satisfaction and quality management: an empirical analysis. International Journal of Operations \& Production Management, 32(3), 308 - 328. http://dx.doi.org/10.1108/01443571211212592

Mirsepassi, N. (2004). Human Resource Strategic Management \& Labour Relation, Mir, twenty - third edition (in Farsi).

Murphy K. S., \& S. Murrmann. (2009). The research design used to develop a high performance management system construct for US restaurant managers. International Journal of Hospitality Management, $28, \quad 547-555$. http://dx.doi.org/10.1016/j.ijhm.2009.03.003

Othman, Rozhan Bin (1996). Strategic HRM: evidence from the Irish food industry. Personnel Review, 25(1), 40-58. http://dx.doi.org/10.1108/00483489610106172

Pfeffer, J. (1994). Competitive Advantage Through People Unleashing the Power of the Work Force, Harvard Business School Press, Boston.

Puc`e`taite R., A. La“msa, \& A. Novelskaite. (2010). Building organizational trust in a low-trust societal context. Baltic Journal of Management, 5(2), 197-217. http://dx.doi.org/10.1108/17465261011045124

Saaty, L. T. (1999). Fundamental of the Analytical Network Process. ISAHP, Kobe, Japan, August 12-14, 1999

Saaty, Thomas L., \& Luis G. Vargas. (2006). Decision Making With The Analytic Network Economic, Political, Social and Technological Applications with Benefits, Opportunities, Costs and Risks by Springer Science+Business Media, LLC

Singh S., T. K. Darwish, A. C. Costa, \& N. Anderson. (2012). Measuring HRM and organisational performance: concepts, issues, and framework. Management Decision, 50(4), 651 - 667. http://dx.doi.org/10.1108/00251741211220282 
Soadat S. (2007). Human Resource Management. SAMT Institute (In Farsi).

Storey, \& Sisson, K. (1993). Managing Human Resources and Industrial Relations. Buckingham, Open University Press.

Ulrich D., \& Beatty D. (2001). From partners to players: extending the HR playing field. Human Resource Management, 40(4), 293-307. http://dx.doi.org/10.1002/hrm.1020

Werbel J. D., \& S. M. DeMarie, (2005). Aligning strategic human resource management and person-environment fit. Human Resource Management Review, 15, 247-262. http://dx.doi.org/10.1016/j.hrmr.2005.10.001

Wright P.M., \& McMahan, G.C. (1992). Theoretical perspectives for strategic human resource management. Journal of Management, 18(2), 295-321. http://dx.doi.org/10.1177/014920639201800205

Wright, P. M., \& S. A. Snell. (1998). Toward a unifying framework for exploring fit and flexibility in strategic human resource management. Academy of Management Review, 23(4), 756-772. 